\title{
Recolonization of intertidal macroalgae in relation to gap size and molluscan herbivory on a rocky shore on the east coast of southern Africa
}

\author{
A. H. Dye \\ Department of Zoology, University of Transkei, P/Bag X1 UNITRA, Umtata, Transkei, South Africa
}

\begin{abstract}
The low intertidal on rocky shores in the Transkei region of southern Africa is characterized by extensive turfs of coralline algae. These turfs are punctuated by small gaps maintained by patellid limpets. Recolonization of macroalgae in experimentally cleared gaps of different sizes $(0.5,0.125$ and $0.03 \mathrm{~m}^{2}$ ) was monitored over $1 \mathrm{yr}$ in an initial experiment and then repeated and monitored over a 2 yг period. All quadrats were rapidly recolonized by a green/brown algal component, consisting of Ralfsia spp., Ulva spp., Enteromorpha spp. and Iyengaria sp. Although this component remained dominant there was some growth of coralline algae (Arthrocardia spp. and Jania spp.). Rate of recolonization was directly related to gap size, with the smallest gaps remaining relatively free of algae, and the largest showing greatest recovery after 12 mo. Even after 24 mo, however, the total algal cover was only between 10 and $50 \%$ of that in undisturbed control quadrats. Grazer density (Patella longicosta, $P$. oculus, Oxystele tabularis) was highest in small gaps and there was a direct relationship between the number of grazers and the ratio of bare rock to algae. A model of the interactions between grazers and algae is discussed in terms of human exploitation of patellid limpets and the implications of this for lowshore community structure.
\end{abstract}

\section{INTRODUCTION}

The structure of rocky intertidal communities reflects the spatial and temporal integration of a number of biotic and abiotic factors. In the case of plant communities numerous studies have attested to the importance of such factors as herbivory (Southward 1956, Raffaelli 1979, Underwood 1980, Underwood \& Jernakoff 1981, Cubit 1984, Jara \& Moreno 1984, Duggins \& Dethier 1985, Geller 1991, Beovich \& Quinn 1992), recruitment (Jernakoff 1983, Sousa 1984), competition (Duggins \& Dethier 1985, Steneck et al. 1991) and disturbance (Emerson \& Zedler 1978, Sousa 1984). These factors generally exert their influence directly by acting on individual plants or their propagules. The complexity of interactions between the components of intertidal communities may, however, result in indirect effects which, although sometimes subtle, can alter community structure in important ways. External forces, such as human exploitation, acting on one or more components of the community, may also affect community structure by causing release from predation or grazing pressure (Moreno et al. 1984, 1986, Oliva \& Castilla 1986).

Some sections of the east coast of southern Africa are subject to shellfish gathering by local people (Lasiak \& Dye 1989, Lasiak 1991). The lower tidal levels of these exploited rocky shores are usually dominated by an extensive turf of coralline algae. Although stable and persistent the turf is often punctuated by gaps of 'bare' rock apparently maintained by grazing molluscs (Branch 1975). The structure of this mosaic, however, differs between exploited areas, where the turf is extensive, and those in which shellfish gathering is restricted and the mosaic consists of mussels, bare rock and coralline algae.

There has been much speculation about the consequences of shellfish gathering on these shores (Siegfried et al. 1985, Hockey \& Bosman 1986, Hockey et al. 1988, Lasiak \& Dye 1989, Lasiak 1991, Dye 1992). One of the major problems has been the difficulty of separating natural variability from anthropogenic ef- 
fects (Dye 1988). Such problems can be resolved by using manipulative experiments to simulate natural disturbance and grazing (Underwood et al. 1983). The aim of the present study was to assess the response of the algal turf community on an exploited shore to experimental disturbance and to make testable predictions about the effects of grazer removal.

\section{METHODS}

Study sites. The study was carried out on an exposed rocky shore at Nqabara, $4 \mathrm{~km}$ south of the Dwesa Nature Reserve, on the east coast of southern Africa $\left(28^{\circ} 50^{\prime} \mathrm{E}_{;} 32^{\circ} 18^{\prime} \mathrm{S}\right)$. The shore, which consists of wavecut shale platforms, experiences moderate to heavy wave action emanating from a southwesterly direction. The low shore (between the neap and spring low tide levels) is covered by an extensive turf of coralline algae about $20 \mathrm{~mm}$ thick consisting mainly of Arthrocardia sp. and Jania sp. (Table 1). Within this turf patellid limpets, such as Patella longicosta and $P$. oculus, and pulmonate limpets, such as Siphonaria aspera, maintain gaps of bare rock varying in area from ca 100 to $400 \mathrm{~cm}^{2}$. Periwinkles (Oxystele tabularis) also graze in these gaps. Although a number of other macro-herbivores occur on these shores, only the keyhole limpet Fissurella natalensis is conspicuous during low tide. The gaps, although devoid of macroalgae, support a biofilm which includes bacteria and microalgae.

Experimental manipulations. Three $10 \mathrm{~m}$ long transects, ca $30 \mathrm{~m}$ apart, were established parallel to the sea and permanently marked with stainless steel rawl

Table 1. Wet-mass composition of the low-shore algal turf at Nqabara. $\left(\mathrm{n}=9 \times 0.5 \mathrm{~m}^{2}\right)$. Species composition and density of grazers (ind $\mathrm{m}^{-2}$ ) are also given

\begin{tabular}{|c|c|}
\hline Species & $\%$ Wet mass $( \pm \mathrm{SD})$ \\
\hline \multicolumn{2}{|l|}{ Corallines } \\
\hline Arthrocardia sp. & $85.2(12.6)$ \\
\hline Jania sp. & $5.3(2.1)$ \\
\hline \multicolumn{2}{|l|}{ Green/brown algae } \\
\hline Ralfsia sp. & $5.1 \quad(4.5)$ \\
\hline Ulva rigida & $1.8 \quad(1.2)$ \\
\hline Acrosorium sp. & $1.8(1.1)$ \\
\hline Iyengaria stellata & $0.8 \quad(0.8)$ \\
\hline Enteromorpha sp. & $0.5 \quad(0.3)$ \\
\hline Species & Density \\
\hline \multicolumn{2}{|l|}{ Primary space grazers } \\
\hline Patella longicosta & $10.1(1.0)$ \\
\hline Siphonaria concinna & $1.4 \quad(1.2)$ \\
\hline Oxystele tabularis & $2.0(1.1)$ \\
\hline
\end{tabular}

bolts at each end. Three treatments, consisting of different sized quadrats from which macroalgae were removed, were established in triplicate at random intervals along each transect, giving a total of 9 replicates per treatment. The dimensions of the cleared areas were $71 \times 71 \mathrm{~cm}, 35 \times 35 \mathrm{~cm}$ and $18 \times 18 \mathrm{~cm}$ respectively and the minimum distance between treatments was $1 \mathrm{~m}$. Macroalgae were cleared from these experimental areas in spring (September) 1989, using a paint scraper and wire brush to simulate heavy grazing. No chemical treatment was applied as this may have contaminated surrounding algae and would have represented an unnatural level of disturbance. Triplicate $71 \times 71 \mathrm{~cm}$ control areas were located in the undisturbed algal turf adjacent to each transect. Composition of the algal turf, on a wet mass basis, was determined from the material obtained from the largest cleared areas. The following September (1990) a second series of manipulations was initiated on the same experimental areas.

The recovery of algae was monitored at monthly intervals using $35 \mathrm{~mm}$ colour slides taken through stainless steel quadrats of appropriate size, divided in the case of the 2 larger sizes, into 100 squares using yellow nylon line. The smallest quadrat was divided into 25 squares. To facilitate correct placement of the quadrats a nylon rope, marked with the positions of the treatments, was stretched between the rawl bolts. The percentage cover of algae and the number of grazers were assessed only in the inner $75 \%$ of the quadrats, leaving the remainder as a buffer zone. The surface area sampled in each treatment was the same each month. Two groups of algae were distinguished, i.e. green/browns and corallines (see Table 1). Monthly sampling was done over a 12 mo period in each experiment, with an additional survey being undertaken 24 mo after the start of the second experiment. Controls were surveyed at the start and after 12 mo in each experiment, as well as after 24 mo in the second experiment. Surveys of algal cover and grazer density $\left(9 \times 0.5 \mathrm{~m}^{2}\right)$ were conducted concommittantly in the nearby Dwesa Nature Reserve.

In order to reduce temporal and spatial dependence, data on grazer density, coralline and green/brown algal cover were obtained from 3 separate subsets $(n=4)$ of each treatment selected randomly each month. Percent cover data were transformed to arcsin and all data tested for normality and homoscedasticity (Zar 1974) prior to analyses of variance which were performed after $3,6,9$ and 12 mo in each experiment. An additional analysis was performed after 24 mo in the second experiment. Where significance was revealed Tukey's HSD test was used for further analysis (Wilkinson 1989). T-tests and Pearson correlation analyses were also used where appropriate. 


\section{RESULTS}

Figs. 1 \& 2 show the recovery of algae and grazers following clearance in Expts 1 and 2 respectively. Patterns of algal recovery were similar in both experiments. Gaps were initially recolonized by green/ brown algae, mainly Ralfsia sp. and Enteromorpha sp. which reached maximum cover (50 to $80 \%$ ) after 1 to 2 mo. Although some variability was evident, green/ brown algae generally declined in all treatments and by the end of the experiments accounted for less than $10 \%$ cover (Figs. $1 \& 2$ ).

Coralline algae (Arthrocardia sp. and Jania sp.) took longer to re-establish and reached maximum cover $(30$ to $40 \%) 4$ mo after clearing. This was despite the fact that the coralline algal crust could not be removed en- tirely. It was observed, however, that the remains of the crust became bleached and either died off or were smothered by green/brown algae. The coralline algae also died back during the experiment but this was most evident in the small clearings where they accounted for approximately $10 \%$ by the end of the experiments (Figs 1 \& 2). Algal cover was considerably lower by the end of the experiments than in adjacent control areas (see below). The ratio of bare rock to algae after 12 mo varied between $0.80( \pm 0.05): 1$ in the largest gaps and $5.67( \pm 1.25): 1$ in the smallest. Although data on the cover of algae in the peripheral buffer zone was not used in the present analysis, it was noted that coralline algae had encroached from the surrounding turf and dominated the periphery by the end of each experiment.
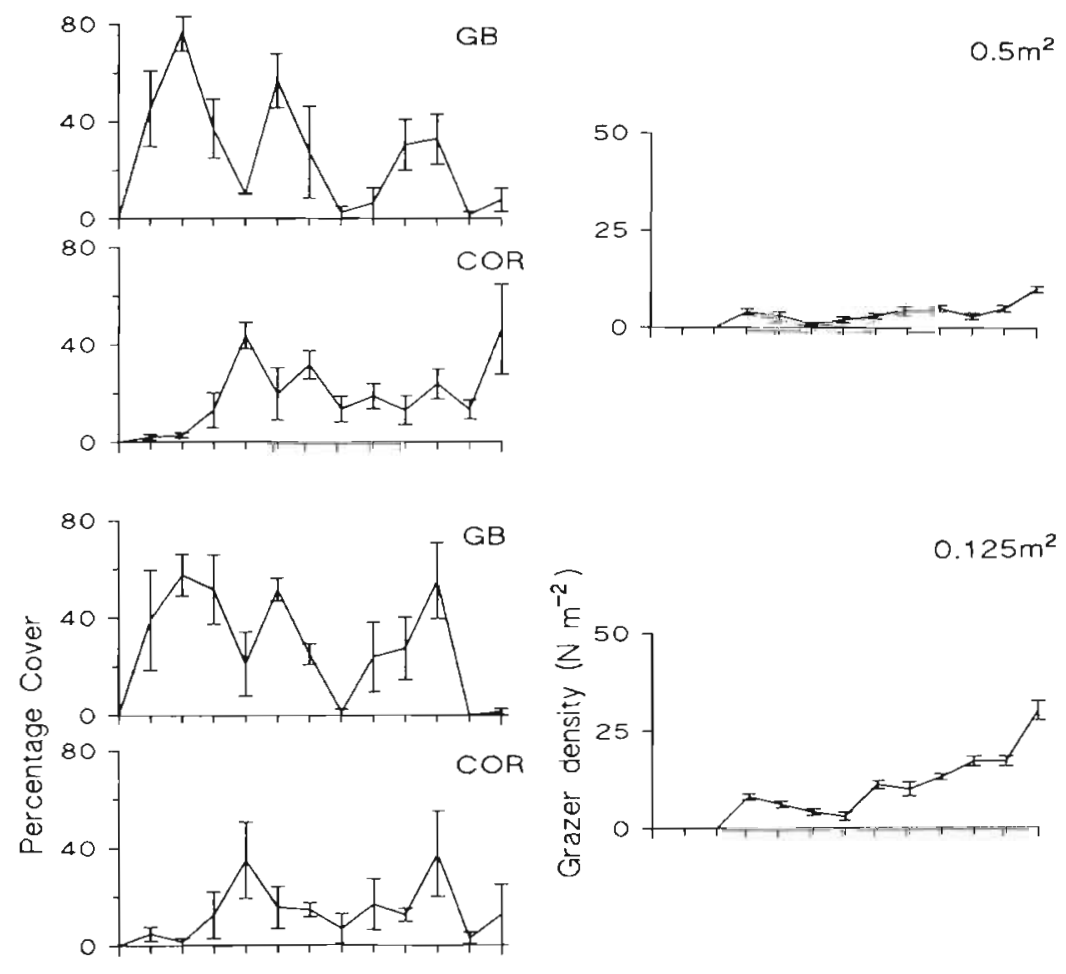

Fig. 1. Recovery of algae and grazers following clearance in Expt 1 (1989 to 1990) GB = green/brown, COR = corallines. Figures on the right indicate gap size. Vertical lines are standard errors $(n=4)$
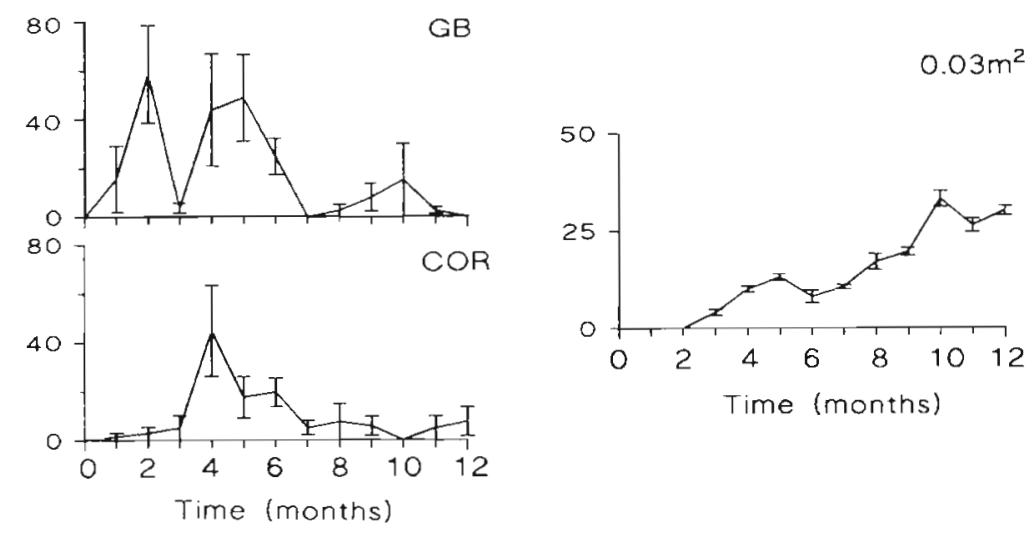

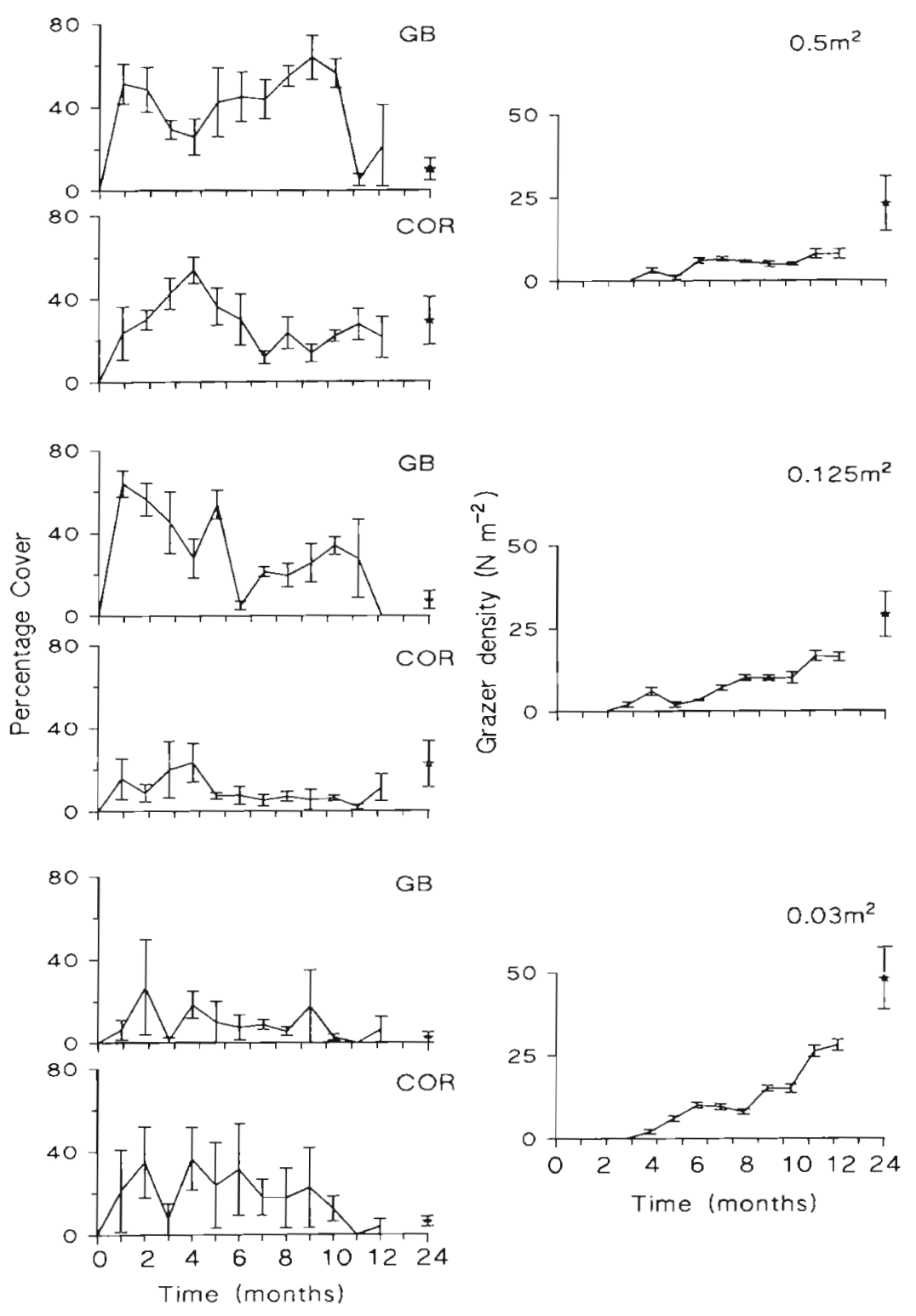

In contrast to the algae, the density of grazers, mainly Patella longicosta and Oxystele tabularis, increased steadily in all treatments after a 2 to 3 mo delay. By 12 mo grazer density was between 8 and 30 $\mathrm{m}^{-2}$ (Fig. 1), and by 24 mo there were 20 to $48 \mathrm{~m}^{-2}$ (Fig. 2). The smallest clearings supported the greatest density of grazers.

Fig. 3 shows the condition of control areas at the beginning and end of each experiment. Also shown are the results of a concommittant survey of algal cover and grazer density in the nearby Dwesa Reserve. In each case the first 12 mo point also serves as the initial survey for the second experiment. Little change occurred in the structure of the community at either site during the experimental periods. At Nqabara coralline algae accounted for more than $80 \%$ cover with only a

Fig. 2. As in Fig 1 but for Expt 2 (1990 to 1992) small amount of green/brown algae present. Total algal cover was rarely less than $95 \%$. At Nqabara the mean ratio of bare rock to algae was $0.14( \pm 0.05): 1$ after 12 mo and $0.11( \pm 0.05): 1$ after 24 mo. The number of grazers varied between 10 and $15 \mathrm{~m}^{-2}$, but declined to $5 \mathrm{~m}^{-2}$ by $24 \mathrm{mo}$.

The cover of algae was significantly lower at Dwesa than at Nqabara (Table 2). Coralline algae rarely exceeded $50 \%$ cover, while $40 \%$ of the substratum was devoid of macroalgae. The green/brown algal component was also slightly more abundant at about $10 \%$ cover. The mean ratio of bare rock to algae was 0.77 $( \pm 0.08): 1$ which was significantly higher than at Nqabara ( $t$-test, $p<0.007, n=9$ ). The number of grazers (16 to 24 ind. $\mathrm{m}^{-2}$ ) was significantly higher at Dwesa ( $t$-test, $\mathrm{p}<0.03, \mathrm{n}=9$ ). 

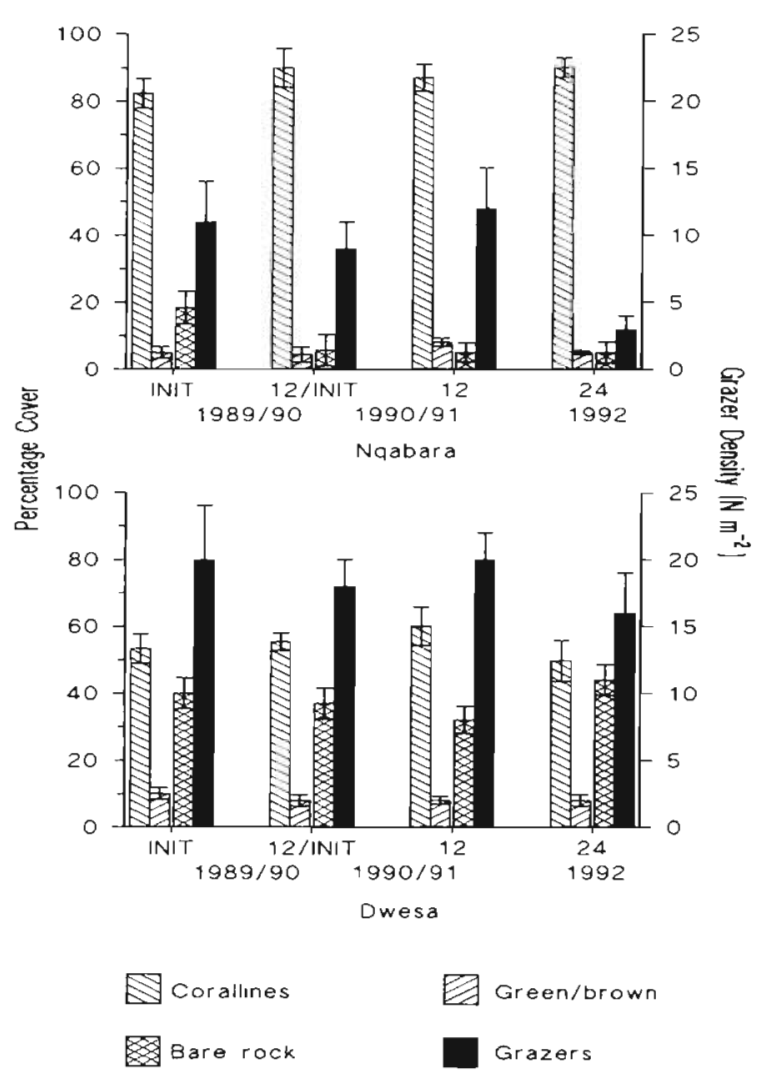

Fig. 3. Algal cover, bare rock area and grazer density, at the beginning and end of each experiment, in $0.5 \mathrm{~m}^{2}$ control quadrats at Nqabara and Dwesa. Vertical lines indicate standard errors $(n=9)$

Table 2. Comparisons of algal cover, bare rock and grazer density in control quadrats at Nqabara and Dwesa. $t$-tests, $\mathrm{n}=9$. NS: not significant

\begin{tabular}{|ccc|}
\hline Time & $t$ & $p$ \\
\hline Initial (1989) & & \\
Corallines & 26.854 & $<0.0001$ \\
Green/brown & -5.116 & $<0.0009$ \\
Bare rock & -6.030 & $<0.0004$ \\
Grazers & -10.444 & $<0.0001$ \\
12 mo (Expt 1) & & \\
Corallines & 15.901 & $<0.0001$ \\
Green/brown & -3.920 & $<0.004$ \\
Bare rock & -8.605 & $<0.0005$ \\
Grazers & -11.627 & $<0.0001$ \\
12 mo (Expt 2) & & \\
Corallines & 27.139 & $<0.0001$ \\
Green/brown & -1.164 & $N 5$ \\
Bare rock & -11.186 & $<0.0001$ \\
Grazers & -15.179 & $<0.0001$ \\
24 mo (Expt 2) & & $<0.0001$ \\
Corallines & 58.357 & $<0.001$ \\
Green/brown & -5.000 & $<0.0001$ \\
Bare rock & -18.127 & $<0.0001$ \\
Grazers & -19.404 & \\
Also represents the initial condition for Expt 2 \\
Al E
\end{tabular}

Table 3. Analysis of variance of percent cover (arcsin) with the factors gap size and algal group for Months 3, 6, 9 and 12 in Expt 1 and Months 3,6, 9, 12 and 24 in Expt. 2. $\mathrm{n}=24$ ( 3 treatments $\times 2$ algal groups $\times 4$ replicates). NS: not significant

\begin{tabular}{|c|c|c|c|c|}
\hline $\begin{array}{l}\text { Elapsed time } \\
\text { Factor }\end{array}$ & $\mathrm{df}$ & MS & $F$ & $\mathrm{p}$ \\
\hline & \multicolumn{3}{|c|}{ Expt 1} & \\
\hline \multicolumn{5}{|l|}{$3 \mathrm{mo}$} \\
\hline Size & 2 & 0.388 & 5.425 & $<0.014$ \\
\hline Algae & 1 & 0.578 & 8.074 & $<0.011$ \\
\hline Size $\times$ Algae & 2 & 0.152 & 2.125 & NS \\
\hline \multicolumn{5}{|l|}{$6 \mathrm{mo}$} \\
\hline Size & 2 & 0.048 & 3.841 & $<0.041$ \\
\hline Algae & 1 & 0.005 & 0.442 & NS \\
\hline Size $\times$ Algae & 2 & 0.012 & 0.980 & NS \\
\hline \multicolumn{5}{|l|}{9 mo } \\
\hline Size & 2 & 0.159 & 2.853 & $<0.084$ \\
\hline Algae & 1 & 0.141 & 2.537 & $<0.0001$ \\
\hline Size $\times$ Algae & 2 & 0.044 & 3.930 & NS \\
\hline \multicolumn{5}{|l|}{$12 \mathrm{mo}$} \\
\hline Size & 2 & 0.166 & 4.122 & $<0.034$ \\
\hline Algae & 1 & 0.227 & 5.628 & $<0.029$ \\
\hline \multirow[t]{2}{*}{ Size $\times$ Algae } & 2 & 0.040 & 1.000 & NS \\
\hline & \multicolumn{3}{|c|}{ Expt 2} & \\
\hline \multicolumn{5}{|l|}{$3 \mathrm{mo}$} \\
\hline Size & 2 & 0.618 & 12.983 & $<0.0001$ \\
\hline Algae & 1 & 0.000 & 0.001 & NS \\
\hline Size $\times$ Algae & 2 & 0.075 & 1.580 & NS \\
\hline \multicolumn{5}{|l|}{$6 \mathrm{mo}$} \\
\hline Size & 2 & 0.282 & 9.431 & $<0.002$ \\
\hline Algae & 1 & 0.011 & 0.378 & NS \\
\hline Size $\times$ Algae & 2 & 0.023 & 0.781 & NS \\
\hline \multicolumn{5}{|l|}{$9 \mathrm{mo}$} \\
\hline Size & 2 & 0.180 & 3.307 & $<0.060$ \\
\hline Algae & 1 & 0.480 & 8.803 & $<0.008$ \\
\hline Size $\times$ Algae & 2 & 0.113 & 2.071 & NS \\
\hline \multicolumn{5}{|l|}{$12 \mathrm{mo}$} \\
\hline Size & 2 & 0.072 & 4.295 & $<0.030$ \\
\hline Algae & 1 & 0.005 & 0.280 & NS \\
\hline Size $\times$ Algae & 2 & 0.010 & 0.607 & NS \\
\hline \multicolumn{5}{|l|}{$24 \mathrm{mo}$} \\
\hline Size & 2 & 0.051 & 3.089 & $<0.070$ \\
\hline Algae & 1 & 0.051 & 3.104 & NS \\
\hline Size $\times$ Algae & 2 & 0.015 & 0.894 & NS \\
\hline
\end{tabular}

Analyses of variance at 3, 6, 9 and $12 \mathrm{mo}$ in the first experiment, as well as at 24 mo in the second, revealed that gap size had a significant influence on the recovery of algae (Table 3). Post-hoc tests consistently revealed that all treatments differed from each other (Tukey HSD; $\mathrm{p}<0.05$ in each case). The largest clearings supported the greatest cover of algae, and by the end of the experiments these gaps had broken up into a mosaic of small areas of bare rock separated by patches of coralline algal turf. In contrast, the small 
Table 4. Analysis of variance of grazer density (ind. $\mathrm{m}^{-2}$ ) with the factor gap size for Months 3,6, 9 and 12 in Expt 1 and Months 3, 6, 9, 12 and 24 in Expt 2. $\mathrm{n}=12$. NS: not significant

\begin{tabular}{|c|c|c|c|c|}
\hline $\begin{array}{l}\text { Elapsed time } \\
\text { Factor }\end{array}$ & $\mathrm{df}$ & MS & $F$ & $p$ \\
\hline & \multicolumn{4}{|c|}{ Expt 1} \\
\hline $3 \mathrm{mo}$ & & & & \\
\hline Size & 2 & 64.000 & 36.000 & $<0.0001$ \\
\hline \multicolumn{5}{|l|}{$6 \mathrm{mo}$} \\
\hline Size & 2 & 134.333 & 36.636 & $<0.0001$ \\
\hline \multicolumn{5}{|l|}{$9 \mathrm{mo}$} \\
\hline Size & 2 & 149.333 & 20.364 & $<0.0001$ \\
\hline \multicolumn{5}{|l|}{$12 \mathrm{mo}$} \\
\hline \multirow[t]{2}{*}{ Size } & 2 & 533.333 & 48.980 & $<0.0001$ \\
\hline & \multicolumn{4}{|c|}{ Expt 2} \\
\hline \multicolumn{5}{|l|}{$3 \mathrm{mo}$} \\
\hline Size & 2 & 5.3 .3 .3 & 6.000 & $<0.022$ \\
\hline \multicolumn{5}{|l|}{$6 \mathrm{mo}$} \\
\hline Size & 2 & 46.083 & 24.761 & $<0.0001$ \\
\hline \multicolumn{5}{|l|}{$9 \mathrm{mo}$} \\
\hline Size & 2 & 100.000 & 37.583 & $<0.0001$ \\
\hline \multicolumn{5}{|l|}{$12 \mathrm{mo}$} \\
\hline Size & 2 & 404.083 & 47.384 & $<0.0001$ \\
\hline \multicolumn{5}{|l|}{$24 \mathrm{mo}$} \\
\hline Size & 2 & 169.333 & 0.301 & NS \\
\hline
\end{tabular}

cleared quadrats were usually devoid of macroalgae. There were no significant interaction terms indicating that gap size affected both groups of algae in a similar way.

Table 4 shows the results of single factor analyses of variance of grazer density as a function of gap size at various times. Gap size had a significant influence on

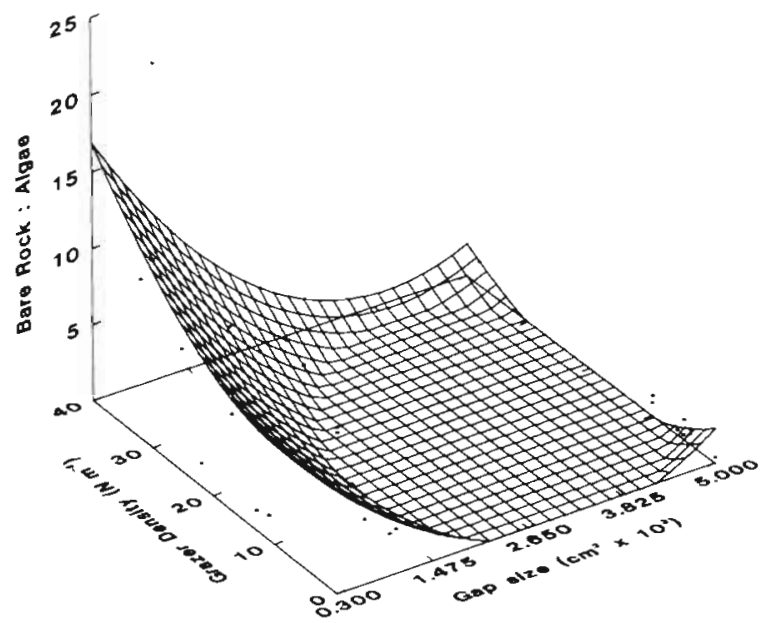

Fig. 4. Graphical representation of the relationship between gap size, grazer density and the ratio of bare rock to algae over time at Nqabara. Expts 1 and 2 combined
Table 5. Pearson correlations between green/brown and coralline algal cover and between grazer density (ind. $\mathrm{m}^{-2}$ ) and algal cover as a function of time (excluding Month 1). NS: not significant

\begin{tabular}{|lcc}
\hline $\begin{array}{l}\text { Time } \\
\text { Factor }\end{array}$ & $\mathrm{r}^{2}$ & $\mathrm{p}$ \\
\hline $\begin{array}{l}\text { Expt } 1(1989 \text { to } 1990 ; \mathrm{n}=33)^{\mathrm{a}} \\
\text { Green/brown vs corallines }\end{array}$ & $\mathrm{NS}$ & \\
Grazers vs green/brown & -0.461 & $<0.007$ \\
Grazers vs corallines & $\mathrm{NS}$ & \\
Grazers vs total cover & -0.486 & $<0.004$ \\
Expt $2(1990 \text { to } 1992 ; \mathrm{n}=36)^{\mathrm{b}}$ & & \\
Green/brown vs corallines & $\mathrm{NS}$ & \\
Grazers vs green/brown & -0.507 & $<0.002$ \\
Grazers vs corallines & $\mathrm{NS}$ & \\
Grazers vs total cover & -0.546 & $<0.001$ \\
Expt 1 vs Expt $2($ excluding 24 month point) & $(\mathrm{n}=33)^{\mathrm{d}}$ \\
Green/brown & 0.586 & $<0.0001$ \\
Coralline & 0.490 & $<0.004$ \\
Total algal cover & 0.717 & $<0.0001$ \\
Grazers & 0.902 & $<0.0001$ \\
& & \\
a $\mathrm{n}=11 \times 3$ treatments & & \\
$\mathrm{n}=12 \times 3$ treatments & &
\end{tabular}

the recruitment of grazers during the first $12 \mathrm{mo}$ in both experiments. Grazer density was invariably highest in the small clearings (Figs. $1 \& 2$ ). Once again posthoc tests revealed that all treatments differed significantly from each other (Tukey HSD; $p<0.001$ in all cases). Gap size had ceased to influence grazer density by 24 mo when all treatments supported a similar density of grazers.

Table 5 shows the results of correlation analyses of algal cover and grazer density with time, which are based on the combined data from the 3 treatments each month (excluding Month 1). There were no significant correlations between the algal groups or between grazer density and coralline algal cover. There were, however, significant negative correlations between green/brown algal cover and grazer density as well as between total algal cover and grazer density. This suggests that the temporal decline in algal cover was due to grazing effects. Also shown in Table 5 are correlations between the 2 experiments in the recovery of the algal groups and grazers (excluding Month 24 in Expt 2). The high positive correlations confirm the impression gained from Figs. 1 \& 2 that the patterns of recovery were similar in each experiment.

The above results indicate that there were significant interactions between gap size, algal recolonization and grazer density. These interactions are summarized in 2 multiple regression models. They are derived from a combination of the data from both experiments and all treatments for Months 3, 6, 9 and 12, 
as well as Month 24 in the second experiment. In the first model the ratio of bare rock to algae (BR:A) is related to time from disturbance $(t)$ and intensity of disturbance ( $s$; expressed as gap size in $\mathrm{cm}^{2}$ ) as follows:

$$
\begin{gathered}
\mathrm{BR}: \mathrm{A}=7.300+0.694 t-8.461 s-0.020 t^{2}+1.273 s^{2} \\
\text { and } \mathrm{r}=0.661, \mathrm{n}=27, \mathrm{p}<0.01
\end{gathered}
$$

In the second model grazer density $(G)$ is related to time and disturbance as follows:

$$
\begin{gathered}
G=-0.390+2.346 t-3.915 s-0.413 t^{2}-0.025 s^{2} \\
\text { and } r=0.909, \mathrm{n}=27, \mathrm{p}<0.0001
\end{gathered}
$$

Fig. 5 gives a graphical representation of the relationship between these 3 parameters. The figure shows that, in the absence of grazers, any gap will tend to become covered by algae and exhibit a low BR:A ratio. This tendency is, however, modulated by increasing grazing pressure. Since this is generally greatest in small gaps, these will tend to have the highest BR: A ratios. The graininess of the low shore mosaic of turf and gaps is thus determined to a large extent by grazing pressure.

\section{DISCUSSION}

The present study has shown that gap size has a significant influence on algal recolonization. Smaller gaps in general exhibit poor recovery compared to large gaps. A similar finding was reported by Sousa (1984) who cleared gaps in beds of Mytilus californianus in northern California, USA. He found that algal recovery was poor at the periphery of gaps and related this to grazing pressure. Grazers, particularly limpets, which invaded the clearings from the surrounding mussel bed, were able to eliminate the grazer-vulnerable algae. The situation at Nqabara differs in that gaps were created within an algal turf which supports relatively few grazers. Recolonization of algae therefore arises through settlement of spores and regrowth of existing thalli as well as through encroachment from the periphery. By the end of the study the cover of algae was higher at the periphery than in the centre in all but the smallest gaps. Grazer-resistant corallines dominated the periphery while the centre was dominated by grazer-vulnerable species such as ulvoids. As found in previous studies it appears that grazer abundance is the key factor in determining the extent and type of algal recolonization (Suchanek 1978, Underwood 1980, 1981, Paine \& Levin 1981, Sousa 1984).

Although the effects of seasonal disturbance were not investigated in the present case, some studies have shown that succession, if not the climax state, is affected by the timing and frequency of disturbance (Dayton 1971, Emerson \& Zedler 1978). Such effects have been short-lived and, given the relative stability and uniformity of the algal turf at Nqabara, it seems unlikely that seasonal fluctuations have long-lasting effects.

How do grazers become established and maintain gaps in the face of encroachment by grazer-resistant algae such as corallines? Since most of the grazers in the present study cannot cross the algal turf because of lack of adhesion (Underwood 1981) only 2 possibilities exist for the establishment of grazers in the cleared areas. Grazers could invade clearings by cutting through from adjacent gaps (see below) or larvae could settle directly into cleared areas. The former was not observed in the present study and it must be concluded that direct settlement occurred. This is supported by the observation that initial grazers were small and, although no measurements were made, appeared to increase in size with time. The grazers studied at Nqabara feed largely on bacteria, diatoms and spores of larger algae. Their control of primary space is therefore indirect and acts through preventing the establishment of macroalgae. In a recent study on the Oregon (USA) coast Farrell (1991) found that limpets initially slowed the rate of recolonization of macroalgae. The eventual establishment of barnacles, however, facilitated the growth of macroalgae by inhibiting the grazing activity of limpets. In a similar study on the east coast of Australia Beovich \& Quinn (1992) found that the limpet Siphonaria diemenensis had a significant effect on the abundance of mid-littoral foliose algae.

The foraging behavior of limpets offers another possibility for maintaining primary space. Individuals of species such as Patella longicosta and $P$. oculus are often found at the edge of gaps partially wedged under the surrounding algal turf. This continual undercutting of the turf could presumably prevent encroachment provided that the gap size was small enough for the grazers to cover the periphery frequently. Large gaps would either break up into smaller gaps by recolonization from within or be reduced in size by encroachment. Furthermore, large grazers would be expected to maintain large gaps and the resulting mosaic would be a function of both the abundance and size of grazers (Geller 1991). The presence of limpets also appears to facilitate the activity of other primary space grazers which, on their own, would be unable to maintain bare rock. Species such as Oxystele tabularis, Cellana capensis and Siphonaria aspera may be favoured by the presence of limpets provided that microalgal productivity is high enough (Dye \& White 1992).

One indicator of low-shore mosaic structure is the 
ratio of bare rock to algae (BR:A). The model derived from the Nqabara data clearly shows the relationship between grazer abundance and BR : A ratio. It predicts that any factor which influences the abundance of grazers will affect the structure of the mosaic. A gap created on a shore on which grazers are scarce will be rapidly recolonized by algae while gaps will persist on shores where grazers are abundant. A comparison of the mosaic at Nqabara with that at Dwesa reveals a much higher ratio of bare rock to algae at Dwesa. According to the model this would result from increased grazing pressure at Dwesa and indeed there are almost twice as many grazers at Dwesa than at Nqabara. Furthermore, Lasiak (1991) found that, among low-shore limpets, Patella oculus was not only more abundant at Dwesa but was also $32 \%$ larger than at Nqabara. Her findings clearly showed that differences in grazer population structure between the 2 shores resulted from human shellfish exploitation. In the present study a significant number of grazers, particularly limpets, colonized the gaps. Presumably these will be removed when they reach harvestable size at $35 \mathrm{~mm}$ (Lasiak 1991) and, unless they are replaced by new recruits, the gaps will become covered by algal turf.

A number of studies have attempted to quantify the effects of this exploitation (Mills 1985, Hockey et al. 1988, Lasiak \& Dye 1989). Some studies have suffered from inadequate temporal and spatial replication (Siegfried et al. 1985, Hockey \& Bosman 1986) and only one has involved limited experimental manipulation (Dye 1992). In that study it was shown that exploitation of mussels (Perna perna) from the infratidal on these shores often results in the establishment of coralline algal turf. It was predicted that grazing pressure would modify the recolonization of mussels in a similar way to that for algae in the present study. The model proposed in the present paper, although limited by its deterministic nature, provides a framework for understanding the structure of the low shore in this region. Extensive algal turfs with small gaps which close rapidly would be predicted on shores subjected to shellfish gathering. In protected areas, however, a more open or grainy mosaic of grazed rock and algal patches would be expected. A greater abundance of grazer species that are normally unexploited would also be expected in protected areas. However, while the evidence at hand is compelling, verification of the model awaits the completion of further experiments which involve the manipulation of grazing pressure.

Acknowledgements. The University of Transkei and the Foundation for Research Development are acknowledged for their financial support. The Transkei Department of Nature Conservation is thanked for permission to work within nature reserves. Dr T Lasiak and D. White, T Barnard and G.
Jenkins are thanked for their assistance in the field at various times.

\section{LITERATURE CITED}

Beovich, E. K., Quinn, G. P. (1992). The grazing effect of limpets on the macroalgal community of a rocky intertidal shore. Aust. J. Ecol. 17: 75-82

Branch, G. M. (1975). Mechanisms reducing competition in limpets: migration, differentiation and territorial behaviour. J. Anim. Ecol. 44: 575-600

Cubit, J. D. (1984). Herbivory and the seasonal abundance of algae on a high intertidal rocky shore. Ecology 65: $1904-1917$

Dayton, P. K. (1971). Competition, disturbance, and community organization: the provision and subsequent utilization of space in a rocky intertidal community. Ecol. Monogr. 41 $351-389$

Duggins, D. O., Dethier, M. N. (1985). Experimental studies of herbivory and algal competition in a low intertidal habitat. Oecologia 67: 183-191

Dye, A. H. (1988). Rocky shore surveillance on the Transkei coast: temporal and spatial variability in the balanoid zone at Dwesa. S. Afr. J. mar. Sci 7: 87-99

Dye, A. H. (1992). Experimental studies of succession and stability in rocky intertidal communities subject to artisanal shellfish gathering. Neth. J. Sea Res. in press

Dye, A. H., White, D. R. A. (1992). Intertidal microalgal production and molluscan herbivory in relation to season and elevation on two rocky shores on the east coast of southern Africa. S. Afr. J. mar. Sci. 11: 483-489

Emerson, S. E., Zedler, J. B. (1978). Recolonization of intertidal algae: an experimental study. Mar. Biol 44: 315-324

Farrell, T. M. (1991). Models and mechanisms of succession an example from a rocky intertidal community. Ecol. Monogr. 61: 95-113

Geller, J. B. (1991). Gastropod grazers and algal colonization on a rocky shore in northern California: the importance of the body size of grazers. J. exp. mar. Biol. Ecol. 150: 1-17

Hockey, P. A. R., Bosman, A. L. (1986). Man as an intertidal predator in Transkei: disturbance, community convergence and the management of a natural food resource. Oikos 46: 3-14

Hockey, P. A. R., Bosman, A. L., Siegfried, W. R. (1988) Patterns and correlates of shellfish exploitation by coastal people in Transkei: an enigma of protein production. J. appl. Ecol. 25: 353-363

Jara, H. F., Moreno, C. A. (1984). Herbivory and structure in a midlittoral community: a case in southern Chile. Ecology 65: $28-38$

Jernakoff, P. (1983). Factors affecting the recruitment of algae in a midshore region dominated by barnacles. J. exp. mar. Biol. Ecol, 67: 17-31

Lasiak, T A. (1991). The susceptibility and/or resilience of rocky littoral molluscs to stock depletion by the indigenous coastal people of Transkei, Southern Africa. Biol. Cons. 56: 245-264

Lasiak, T. A., Dye, A. H. (1989). The ecology of the brown mussel Perna perna in Transkei, Southern Africa: Implications for the management of a traditional food resource. Biol. Cons. 47: 245-257

Mills, C. G. (1985). Shellfish utilization and its effect on rocky shore biota in Transkei. M. Sc. thesis, Univ. of Cape Town

Moreno, C. A., Sutherland, J. P., Jara, H. F. (1984). Man as predator in the intertidal zone of southern Chile. Oikos 42: $155-160$ 
Moreno, C. A., Lunecke, K. M., Lepez, I. (1986). The response of an intertidal Choncholepas (Gastropoda) population to protection from man in southern Chile and the effects on benthic sessile assemblages. Oikos 46: $358-364$

Oliva, D., Castilla, J. C. (1986). The effect of human exclusion on the population structure of keyhole limpets Fissurella crassa and $F$. limbata on the coast of central Chile. P.S.Z.N.I. Mar. Ecol. 7. 201-217

Paine, R. T., Levin, S. A. (1981). Intertidal landscapes: disturtance and the dynamics of pattern. Ecol. Monogr. 51: $145-178$

Raffaelli, D. (1979). The grazer-algae interaction in the intertidal zone on New England rocky shores. J. exp. mar. Biol. Ecol. 38: 81-100

Siegfried, W. R., Hockey, P. A. R., Crowe, A. A. (1985). Exploitation and conservation of brown mussel stocks by coastal people of Transkei. Environ. Conserv. 12: $91-104$

Sousa, W. P. (1984). Intertidal mosaics: patch size, propagule availability, and spatially variable patterns of succession. Ecology 65: 1918-1935

Southward, A. J. (1956). The population balance between limpets and seaweed on wave-beaten rocky shores. Rep. Mar. Biol. Stn Port Erin 68: 20-29

Steneck, R. S., Hacker, S. D., Dethier, M. N. (1991).

This article was submitted to the editor
Mechanisms of competitive dominance between crustose coralline algae: an herbivore-mediated competitive reversal. Ecology 72: 938-950

Suchanek, T. H. (1978). The ecology of Mytilus edulis L. in exposed rocky intertidal communities. J. exp. mar. Biol. Ecol. 31. $105-120$

Underwood, A. J. (1980). The effects of grazing by gastropods and physical factors on the upper limits of distribution of intertidal macroalgae. Oecologia 46: 201-213

Underwood, A. J. (1981). Structure of a rocky intertidal community in New South Wales: patterns of vertical distribution and seasonal changes. J. exp. mar Biol. Ecol. 51: $57-85$

Underwood, A. J., Jernakoff, P. (1981). Effects of interactions between algae and grazing gastropods on the structure of a low-shore intertidal algal community. Oecologia 48: $221-233$

Underwood, A. J., Denley, E. J., Moran, M. J. (1983). Experimental analyses of the structure and dynamics of mid shore rocky intertidal communities in New South Wales. Oecologia 56: 202-219

Wilkinson, L. (1989). Systat: the system for statistics. Systat Inc., Evanston, IL, p. 547

Zar, J. H. (1974). Biostatistical analysis. Prentice-Hall, New York

Manuscript first received: May 19, 1992

Revised version accepted: January 14, 1993 